\title{
Angelika Czajkowska
}

ORCID: 0000-0003-3474-3286

angelika.maria.czajkowska@gmail.com

\section{REAL-TIME MARKETING JAKO FORMA PROMOCJI NA PRZYKŁADZIE MAREK IKEA ORAZŻYWIEC}

\section{Abstract \\ REAL-TIME MARKETING AS A FORM OF PROMOTION ON THE EXAMPLE OF THE IKEA AND ŻYWIEC BRANDS}

Real-time marketing is a phenomenon that is increasingly used in marketing activities of companies. Brands strive to establish and maintain close relations with their target group by referring to many issues, including popular natural phenomena or pop culture. In this article, the author analyzes real-time marketing activities of the IKEA and Żywiec brands on the social networking site called Facebook in the years 2014-2019. The aim of the study was a comparative analysis of published posts in terms of their graphic layout, shared messages as well as descriptions. The author also presented issues that were used by Żywiec and IKEA to implement real-time marketing activities.

Key words: real-time marketing, marketing, forms of promotion, Żywiec, IKEA

\section{Wprowadzenie}

Real-time marketing (RTM) stanowi „zdolność do budowania działań marketingowych, «tu i teraz», czyli tworzenie interesującego contentu w taki sposób, by na bieżąco odpowiadać na zjawiska popkulturowe oraz mówić o tym, czym żyją klienci”'. RTM to także „dostarczenie odpowiedniej oferty dla danego klienta we właściwym miejscu i czasie"2. Aby wykonać to zadanie, niezbędne jest przygotowanie

${ }^{1}$ P. Ledzian, Real-Time Marketing, [w:] M. Czajkowska, M. Malarski (red.), Funkcjonowanie e-biznesu. Zasoby, procesy, technologie, Wydawnictwo Uniwersytetu Łódzkiego, Łódź 2015, s. 90.

${ }^{2}$ K. Szymańska, Wykorzystanie real-time marketingu jako narzędzia budowania wizerunku firmy w social media, „Zarządzanie Mediami” 2015, t. 3, nr 4, s. 270, http://www.ejournals.eu/ZM/Tom3/4-2015/art/7193/ (dostęp: 5.09.2019). 
spersonalizowanej oferty po przeanalizowaniu uprzedniej historii zakupów oraz zwyczajów nabywczych klienta ${ }^{3}$.

Pojęcie real-time marketing było wykorzystywane już w latach 90., jednak to właśnie w obecnych czasach stanowi ono istotne narzędzie do realizacji cyfrowych działań strategicznych ${ }^{4}$. Podczas jego stosowania należy nawiązać do określonej sytuacji jak najszybciej, najlepiej w ciągu kilku minut, a nawet sekund ${ }^{5}$.

Na rozwój RTM znaczący wpływ miało upowszechnienie Internetu, który stał się nowym medium komunikacyjnym.

Użytkownik, który dotychczas był głównie odbiorcą treści, jakie zostały mu zaproponowane przez twórcę" czy zespół redagujący dany serwis, stał się podstawowym i najważniejszym dostarczycielem treści w serwisie internetowym ${ }^{6}$.

Dystans pomiędzy odbiorcą i nadawcą znacząco się zmniejszył, a ich wzajemna komunikacja przybrała formę dialogu. Na upowszechnienie real time marketingu wpłynęła także rosnąca popularność smartfonów (w tym mobilnych aplikacji) ${ }^{7}$ oraz social media.

Media społecznościowe to platformy online stanowiące przestrzeń dla wypowiedzi użytkowników, którzy wyrażają je w postaci wiadomości tekstowych, filmów bądź plików audio. Za pomocą aplikacji Web 2.0 użytkownicy dzielą się swoimi ideami i opiniami z innymi ${ }^{8}$. Real-time marketing jest również wykorzystywany w działaniach z zakresu content marketing $u^{9}$. Można go zastosować w wielu różnorodnych obszarach, m.in. w wielokanałowej obsłudze klienta, interakcjach $\mathrm{z}$ fanami, działaniach PR-owych podczas kryzysów oraz reakcjach na istotne wydarzenia bądź trendy ${ }^{10}$.

\section{Istota real-time marketingu}

RTM wymaga od twórców refleksu, a także zdolności prowadzenia dyskusji z odbiorcami (rozmowa, odpowiedź na pytania bądź komentarze). Istotne jest również bardzo szybkie reagowanie na zmiany w otoczeniu i komunikowanie ich odbiorcom.

3 Tamże.

${ }^{4}$ M.E. Summak, I. Ar1, The Influence of Real-Time Marketing on Social Media Users: A Study on Users of 'Ekşi Sözlük', „Sosyal Bilimler Meslek Yüksekokulu Dergisi” 2015, vol. 18, nr 1, s. 61.

5 Tamże, s. 62.

${ }^{6}$ B. Gregor, J. Kłosińska, Zastosowanie koncepcji real-time marketingu w komunikacji z klientem, „Zeszyty Naukowe Uniwersytetu Szczecińskiego. Ekonomiczne Problemy Usług” 2015, nr 117, s. 113.

7 W.C. Sanchez Torres, J.C. Restrepo, Strategic Real-Time Marketing, [w:] D. Juárez Varón, M. Expósito Langa, J.V. Tomás Miquel, M. Cruz Fernández Madrid (red.), Marketing Research Notebooks, Editorial ISEUN, Alicante 2015, s. 173-174.

${ }^{8}$ M.E. Summak, I. Ar1, The Influence of..., dz. cyt., s. 59-60.

9 Tamże, s. 62.

${ }^{10}$ B. Gregor, J. Kłosińska, Zastosowanie koncepcji..., dz. cyt., s. 114. 
Wiadomości tworzone przez organizacje powinny być kreatywne, atrakcyjne oraz szybkie, aby stać się tzw. viralem, który będzie udostępniany przez użytkowników i tym samym będzie promował określoną markę lub produkt bardzo niskim kosztem $^{11}$. W konsekwencji wzrosną także pozytywne emocje odbiorców względem marki ${ }^{12}$, co wpłynie korzystnie na jej wizerunek oraz zasięg komunikatu ${ }^{13}$.

\section{Zasady działania RTM}

Wiadomości przesyłane do użytkowników powinny być przygotowywane na podstawie odpowiednich danych i wymagać od odbiorców zaangażowania oraz realizacji odpowiednich działań. W tym celu wykorzystuje się m.in. wiadomości e-mail $\mathrm{z}$ rekomendacją lub przypomnieniem o produktach znajdujących się w koszyku, czaty na żywo, zachęcające komunikaty (np. gratulujące użytkownikowi postępu w grze), wiadomości z okazji rocznicy (m.in. urodzin, uczestnictwa w programie bądź zakupu określonego produktu lub usługi) czy pop-upy (prezentacja produktu, a także zachęcenie użytkownika do subskrypcji lub zapisania się do newslettera). Istotne jest również wykreowanie pilności określonego komunikatu przez odliczanie do zakończenia promocji bądź rozpoczęcia sprzedaży produktu ${ }^{14}$. Udostępniane treści muszą być autentyczne i spójne z codzienną komunikacją. Należy je także na bieżąco monitorować, nawet poza standardowymi godzinami pracy, oraz wzmocnić ich przekaz, wykorzystując w tym celu inne kanały komunikacji.

\section{Narzędzia RTM}

RTM w social media jest wdrażany za pomocą dwóch głównych rozwiązań, tj. marketingu treści oraz marketingu w rozmowie. Marketing treści polega na publikacji komunikatu stanowiącego reakcję na obecne wydarzenia. Zazwyczaj jest to krótki przekaz prezentujący produkt firmy. Natomiast marketing w rozmowie to obserwacja dialogu użytkowników sieci i nawiązanie do marki oraz jej produktów w najbardziej stosownym momencie.

Organizacje stosują także tzw. memejacking, który polega na analizie popularnych memów tworzonych przez użytkowników, a następnie wykorzystaniu ich potencjału na potrzeby marki. Dzięki podjętym działaniom firma w oczach odbiorców jest postrzegana jako bardzo kreatywna i interesująca.

11 W.C. Sanchez Torres, J.C. Restrepo, Strategic Real-Time..., dz. cyt., s. 176.

12 P. Ledzian, Real-Time Marketing..., dz. cyt., s. 91.

13 B. Gregor, J. Kłosińska, Zastosowanie koncepcji..., dz. cyt., s. 115-116.

${ }_{14}$ BlueVenn, Real-Time Marketing Tactical Guide, s. 5-16, https://www.bluevenn.com/hubfs/_ files/Real-Time\%20Marketing\%20Tactical\%20Guide\%20eBook.pdf (dostęp: 5.09.2019). 


\section{Plan kampanii RTM}

Przedsiębiorstwa, które chcą na bieżąco udostępniać określone treści, powinny stworzyć kalendarz eventów, a także opracować ewentualne scenariusze komunikacji w różnych kanałach, takich jak social media, wiadomości e-mail, strony internetowe oraz outdoor. Konieczne jest również przygotowanie odpowiedniej grafiki zwracającej uwagę odbiorców.

W sytuacji, gdy przedsiębiorstwo nie zaobserwowało żadnych przełomowych informacji, może ono na przykład udostępnić interesujący komentarz bądź post o evencie firmowym czy pogodzie. Należy jednak pamiętać, że proces komunikacji musi być zrozumiały i interesujący dla odbiorcy ${ }^{15}$.

W działaniach z zakresu RTM konieczne jest przestrzeganie pięciu istotnych zasad $^{16}$ :

- identyfikacja oraz poznanie odbiorcy;

- wyznaczenie celu związanego z obecnością marki w kanałach komunikacyjnych;

- planowanie komunikacji, tj. wyznaczenie obszarów oraz wartości marki, które należy przekazać odbiorcom w celu przyspieszenia ich procesu decyzyjnego, a także podjęcie szybkiego i odważnego działania niezbędnego do natychmiastowej reakcji na zaistniałą sytuację;

- monitoring social media, umożliwiający identyfikację obecnych trendów, a także zachowań odbiorców.

Niezbędne jest również, aby marki wykorzystujące RTM zapewniły odbiorcom dostęp do aktualnych danych na jej temat oraz przekazywały im informację zwrotną. Powinny skupić się na poziomie satysfakcji odbiorcy i zdobyciu jego lojalności, a także ciągle się doskonalić oraz podążać za nowymi trendami ${ }^{17}$. Należy pamiętać, że podczas wdrażania działań z zakresu real-time marketingu nie ma konieczności całkowitej modyfikacji strategii marketingowej ${ }^{18}$, ponieważ RTM stanowi jedynie taktykę działań wykorzystującą określone narzędzia marketingowe w zakresie komunikacji marki.

Działania z zakresu RTM można zaplanować lub nie. Działania zaplanowane stanowią m.in.: eventy firmowe, sytuacje, które mogą się wydarzyć (np. otrzymanie nagrody), wykorzystanie analiz predykcyjnych (wyświetlanie konsumentom określonych produktów na podstawie ich wyszukiwania i historii zakupów), obsługa klienta czy rozpatrywanie skarg. To ostatnie jest najbardziej spontanicznym oraz trudnym wyzwaniem, z jakim firmy muszą się zmierzyć. Należy zatem ciągle monitorować, czy prezentowane treści są pozytywne, oraz śledzić rozwój określonego

15 ProperAD.pl, Real-Time Marketing i jego sekrety, 2019, https://properad.pl/artykul/63/RealTime-Marketing-i-jego-sekrety (dostęp: 22.09.2019).

16 Tamże.

17 P. Ledzian, Real-Time Marketing..., dz. cyt., s. 90.

${ }_{18}$ M.E. Summak, I. Ar1., The Influence of..., dz. cyt., s. 62. 
wydarzenia. Działania z zakresu RTM mogą zająć kilka dni, a nawet tygodni, w zależności od zainteresowania odbiorców ${ }^{19}$. Co więcej, każdego dnia w sieci tworzy się wiele różnorodnych trendów i możliwości, w które mogą zaangażować się marki. Aby osiągnąć zamierzone efekty, należy jednak nawiązywać do trendów interesujących wyznaczoną grupę odbiorców ${ }^{20}$.

Działania nieplanowane stanowią większość działań z zakresu RTM. Podczas kreowania spontanicznych komunikatów nie wolno zapomnieć o tym, że muszą być one spójne $z$ wizerunkiem oraz pozycją marki na rynku. Powinny także posiadać angażującą treść oraz trafnie nawiązywać do zaistniałej sytuacji. Zaleca się komunikowanie głównie pozytywnych lub neutralnych wydarzeń, które zainteresują grupę docelową ${ }^{21}$.

\section{Korzyści i zagrożenia wynikające z wykorzystania RTM}

Działania z zakresu RTM przynoszą bardzo korzystne rezultaty. Organizacja ma szansę zbliżyć się do odbiorców komunikatów, a także nawiązać z nimi unikatowe relacje. Zwiększa się również zasięg przekazu oraz zaufanie względem marki. Podczas procesu komunikacji marka ma też możliwość pozyskania informacji o odbiorcach w czasie rzeczywistym, które będzie można wykorzystać w przyszłości. Co więcej, działania z zakresu RTM prowadzone w mediach społecznościowych generują niskie koszty, które skutkują wysoką efektywnością. Komunikat pozostaje w sieci do momentu jego usunięcia, tak więc określony temat może być omawiany nieskończenie długo ${ }^{22}$. RTM wpływa także korzystnie na nawiązanie bliższego kontaktu z klientem, wzrost jego zaangażowania i lojalności wobec marki oraz wdrażanie działań z zakresu marketingu doświadczeń. Budowana jest również świadomość marki i zmniejsza się poziom utraty klienta ${ }^{23}$.

Niestety, wdrażanie działań z zakresu real-time marketingu może także wiązać się z pewnymi zagrożeniami, szczególnie gdy działania te są prowadzone za pomocą mediów społecznościowych. Pierwszym z nich jest brak poczucia przewidywalności rozwoju marki. Jeżeli jednak działania z zakresu RTM zostaną zawarte w strategii marketingowej firmy, stabilizacja rozwoju zostanie utrzymana. Kolejne zagrożenie stanowi ryzyko obniżenia cen produktów stanowiących zapasy organizacji, szybkie rozpowszechnienie jej negatywnego wizerunku, a także nawiązanie

19 R. Lieb, Real-Time Marketing: The Ability to Leverage Now, 2013, s. 5-8, https://rebeccalieb. com/sites/default/files/downloads/1312\%20Real-Time\%20Marketing\%20RL.pdf (dostęp: 18.09.2019).

${ }^{20}$ W.C. Sanchez Torres, J.C. Restrepo, Strategic Real-Time..., dz. cyt., s. 174-175.

${ }^{21}$ M. Kieżel, Reakcje przedsiębiorstwa na wydarzenia kulturalne jako przejaw stosowania real-time marketingu, „Studia Ekonomiczne. Zeszyty Naukowe Uniwersytetu Ekonomicznego w Katowicach" 2018 , nr 371, s. 24-25.

22 Tamże, s. 22-23.

${ }^{23}$ K. Szymańska, Wykorzystanie real-time marketingu..., dz. cyt., s. 271. 
zbyt bliskich relacji z konsumentami. Dlatego też istotna jest bardzo szybka reakcja na komunikaty odbiorców ${ }^{24}$.

Dlaczego działania z zakresu RTM są skuteczne? Ponieważ obecnie odbiorcy oczekują jak najszybszej odpowiedzi na postawione pytania, a ponad $70 \%$ użytkowników Internetu w Polsce korzysta z wielu ekranów w tym samym czasie. Coraz częściej komentują oni także określone posty bądź wydarzenia. Dzięki takim działaniom w dość szybkim czasie firma wykorzystuje content stworzony przez użytkowników, a świadomość i wiarygodność marki zwiększają się. Poprawie ulegają także relacje pomiędzy nadawcą oraz odbiorcą, szczególnie gdy klienci publikują komunikaty związane z marką, zwiększając tym samym jej autentyczność, liczbę odbiorców oraz zasięg geograficzny ${ }^{25}$.

Organizacje powinny też odpowiadać na posty użytkowników, być kreatywne i rezygnować z publikacji niedopracowanych komunikatów. Zaleca się także, aby udostępnić wiadomość w ciągu dwóch minut oraz dodać odpowiedni hasz$\operatorname{tag}^{26}$. Hasztagi nawiązują do określonego trendu bądź wydarzenia i dzięki nim wiadomość jest dostępna dla szerszego grona odbiorców. Do komunikacji najczęściej dołącza się również elementy wizualne, które są powiązane $\mathrm{z}$ tematem przekazu oraz marką i zwiększają jej rozpoznawalność. Skuteczność działać z zakresu RTM podkreśla także fakt, że komunikat wizualny przekazywany podczas nieoficjalnej komunikacji ( $\mathrm{z}$ ust do ust) wpływa pozytywnie na dzielenie się określoną postawą 27 .

\section{Analiza działań z zakresu real-time marketingu na przykładzie marek Żywiec oraz IKEA}

\section{Marka Żywiec}

Żywiec stanowi flagową markę Grupy Żywiec SA i jest najbardziej rozpoznawalnym polskim piwem za granicą ${ }^{28}$. W skład grupy wchodzą także inne marki, takie jak m.in. Heineken, Warka czy Tatra ${ }^{29}$.

W ostatnim czasie Grupa Żywiec wyznaczyła nową misję oraz wizję organizacji, która będzie obowiązywać przez trzy lata, począwszy od 2020 roku. Misją

24 Tamże, s. 272.

25 D. Szarf, Real-Time Marketing - na czym polega i od czego zacząć?, https://blog.brand24.pl/ real-time-marketing-na-czym-polega-i-od-czego-zaczac/ (dostęp: 20.09.2019).

26 Tamże.

27 L.M. Willemsen, K. Mazerant, A.L. Kamphuis, G. van der Veen, Let's Get Real (Time)! The Potential of Real-Time Marketing to Catalyze the Sharing of Brand Messages, „International Journal of Advertising” 2018, vol. 37, nr 5, s. 835-836.

28 Zob. https://grupazywiec.pl/marki/zywiec/ (dostęp: 26.10.2019).

29 Zob. https://grupazywiec.pl/o-firmie/ (dostęp: 14.01.2020). 
Grupy jest rozwijanie trwałych relacji z klientami oraz konsumentami i odkrywanie przed nimi „czaru piwa” poprzez wykorzystanie w tym celu pasji pracowników. Wizję marki stanowi natomiast zbudowanie najbardziej podziwianej, innowacyjnej oraz efektywnej firmy w branży napojów do 2020 roku. Do tej pory misją oraz wizją organizacji był „ciągły rozwój i doskonalenie relacji z klientami i konsumentami"30.

W swoich działaniach Grupa Żywiec kieruje się także trzema głównymi wartościami, takimi jak wnoszenie radości w życie, szacunek dla jednostek, społeczeństwa oraz planety, a także pasja do jakości oferowanych produktów. Marka należy do segmentu premium i cechuje ją m.in. odwaga oraz dynamika.

Grupę docelową marki Żywiec stanowią zarówno osoby młode w przedziale wiekowym 25-35 lat (nowa odsłona marki) ${ }^{31}$, jak i starsi mężczyźni, którzy doceniają tradycję i historię warzenia piwa, a także najwyższą jakość produktu (pierwotna grupa docelowa). Firma stara się więc w podejmowanych działaniach łączyć tradycję z nowoczesnością ${ }^{32}$.

W swojej strategii marketingowej Żywiec nawiązuje do historii produktu, który powstaje w Arcyksiążęcym Browarze w Żywcu, jego prostego składu (zawierającego wyłącznie trzy składniki), a także świadomości marki poza granicami kraju, m.in. w USA, Kanadzie, Irlandii, Australii czy Hiszpanii. Wspiera również wydarzenia kulturowe, takie jak np. Męskie Granie, czyli jedno z najpopularniejszych i uznanych wydarzeń muzycznych w Polsce.

Grupa oferuje wiele różnego rodzajów piw, m.in. Żywiec Jasne Pełne, Żywiec Bezalkoholowe, Żywiec Bock, Żywiec APA czy Żywiec Marcowe ${ }^{33}$.

Głównymi kanałami komunikacji marketingowej marki są zarówno telewizja, jak i media cyfrowe, w tym omawiane w niniejszym artykule media społecznościowe. Natomiast za najbardziej pożądane trendy w 2020 roku uważa dalszy wzrost popularności piw kraftowych oraz bezalkoholowych. Planuje się także wzmocnić działania związane ze zrównoważonym rozwojem, a więc m.in. chęcią prowadzenia zdrowego trybu życia przez odbiorców ${ }^{34}$.

${ }^{30}$ Grupa Żywiec, Warzymy lepszy świat. Raport wpływu grupy kapitałowej Żywiec za 2016 rok, s. 18-19, https://grupazywiec.pl/wp-content/uploads/2017/08/Warzymy-Lepszy- \%C5\%9Awiat-Raport-wp\%C5\%82ywu-Grupy-Kapita\%C5\%82owej-\%C5\%BBywiec-za-2016-rok-16-sierpnia.compressed.pdf (dostęp: 14.01.2020).

${ }_{31}$ Money.pl, Marka Żywiec odmładza wizerunek, 2013, https://manager.money.pl/news/artykul/ marka;zywiec;odmladza;wizerunek,164,0,1272484.html (dostęp: 13.01.2020).

${ }^{32}$ P. Andrzejewska, Wykorzystanie marketingu internetowego w podnoszeniu konkurencyjności przedsiębiorstw branży browarniczej w Polsce (rozprawa doktorska), 2016, https://r.uek.krakow.pl/ bitstream/123456789/2803/1/1200003254.pdf (dostęp: 13.01.2020).

${ }_{33}$ Zob. https://grupazywiec.pl/marki/zywiec/ (dostęp: 14.01.2020).

${ }^{34}$ J. Gugniewicz, Marki na przełomie 2019/2020: Żywiec, 2019, https://nowymarketing. pl/a/24301,marki-na-przelomie-2019-2020-zywiec (dostęp: 14.01.2020). 


\section{Marka IKEA}

IKEA to jedna $\mathrm{z}$ najpopularniejszych na świecie marek $\mathrm{w}$ branży wyposażenia domu, która została założona w Szwecji ${ }^{35}$. Misją organizacji jest „tworzenie wyjątkowej wartości dla Klienta poprzez rozwój mocy produkcyjnych, będących naszą unikatową przewagą konkurencyjną. Razem - wnosimy wkład w cały łańcuch wartości, zapewniając wiedzę o produkcji i będąc dobrym przykładem we wszystkich aspektach biznesu” ${ }^{36}$, natomiast wizję organizacji stanowi „tworzenie lepszych warunków codziennego życia dla wielu ludzi”37.

Najważniejszymi wartościami dla IKEA są: poczucie wspólnoty, troska o ludzi i planetę, świadomość kosztów, prostota, poszukiwanie ulepszeń i nowych rozwiązań, nieszablonowe myślenie, dawanie i branie odpowiedzialności, a także przywództwo poprzez przykład ${ }^{38}$.

Klientami marki są kobiety i mężczyźni powyżej 22. roku życia, m.in. młode, samotne osoby, które opuściły dom rodzinny, młode małżeństwa bez dzieci, studenci, pracownicy oraz specjaliści. To również osoby spokojne i zdeterminowane, należące do niższej klasy społecznej, robotniczej lub średniej ${ }^{39}$.

Strategia komunikacji marki polega na wykorzystaniu różnych technik promocyjnych, m.in. dystrybucji katalogów promocyjnych, które stanowią najskuteczniejszy i najczęściej wykorzystany kanał komunikacji. Katalog jest dostępny w wersji drukowanej oraz cyfrowej i prezentuje zarówno inspiracje wyposażenia domu, jak i historie prawdziwych osób. Oprócz katalogów marka wykorzystuje także tradycyjne oraz cyfrowe kanały komunikacji, tworząc np. oddzielne profile w mediach społecznościowych dla każdego kraju, w którym działa. Podkreśla również konieczność zaangażowania w zrównoważony rozwój, co pomogło jej zbudować silny wizerunek ${ }^{40}$.

Zdaniem marki najbardziej pożądanymi trendami w 2020 roku będzie m.in. personalizacja komunikacji, komercyjne wykorzystanie wirtualnej rzeczywistości (VR i AR), a także dbanie o zrównoważony rozwój organizacji.

Należy zatem wskazać, iż zarówno IKEA, jak i Żywiec komunikują się głównie z młodymi osobami, które cenią dynamiczny styl życia ${ }^{41}$, wykorzystują w tym celu m.in. media cyfrowe, takie jak social media.

${ }^{35}$ Zob. https://www.ikea.com/pl/pl/this-is-ikea/about-ikea/ (dostęp: 26.10.2019).

${ }_{36}$ Zob. https://www.industry.ikea.pl/index/o-nas/kultura-i-wartosci/ (dostęp: 14.01.2020).

37 Tamże.

38 Tamże.

39 J. Dudowskiy, IKEA Segmentation, Targeting and Positioning: Targeting Cost-Conscious Customers, 2019, https://research-methodology.net/ikea-segmentation-targeting-positioning-targeting-cost-conscious- customers/ (dostęp: 13.01.2020).

${ }^{40}$ Essays, UK, Ikea Communication Strategy in the Global Environment, 2018, https://www.ukessays.com/essays/marketing/a-case-study-of-ikea-with-global-communication-marketing-essay.php (dostęp: 14.01.2020).

${ }^{41}$ J. Gugniewicz, Marki na przełomie 2019/2020: IKEA, 2019, https://nowymarketing.pl/a/24344, marki-na-przelomie-2019-2020-ikea (dostęp: 14.01.2020). 
W niniejszej analizie autorka odwołuje się do czterech przykładów działań z zakresu real-time marketingu, które były wspólne dla obu marek. Nawiązywały one do astronomii oraz popkultury (filmografii - Star Wars i Gra o tron, a także pary książęcej Wielkiej Brytanii).

Rysunek 1. Grafiki reklamowe zamieszczone na profilu marki IKEA na Facebooku
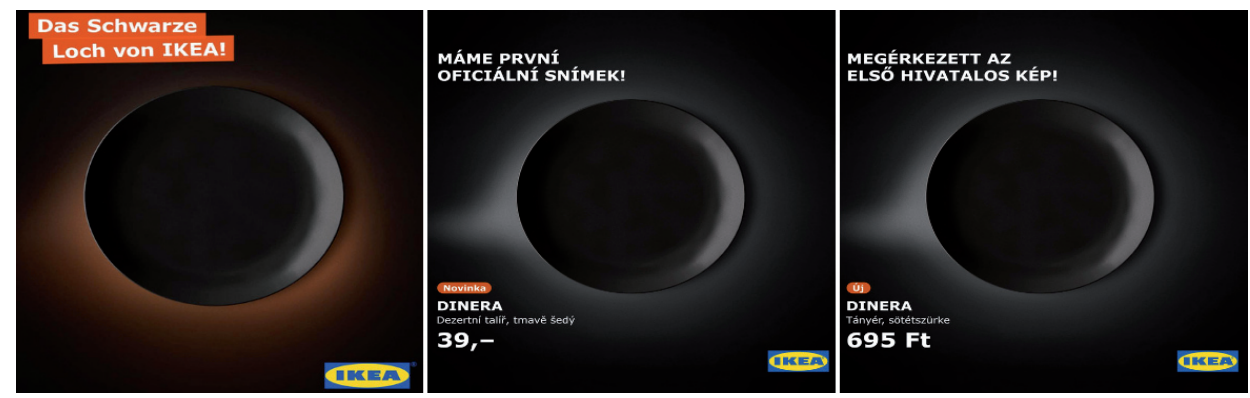

Źródło: https://www.facebook.com/IKEA.Austria, https://www.facebook.com/IKEAceska, https://www. facebook.com/IKEAHU (dostęp: 3.09.2019).

Analizowany przykład jest związany z astronomią, a dokładniej z opublikowaniem pierwszego zdjęcia czarnej dziury. Zostało ono wykonane w 2019 roku podczas realizacji projektu Teleskop Horyzontu Zdarzeń, który polegał na obserwacji centrum

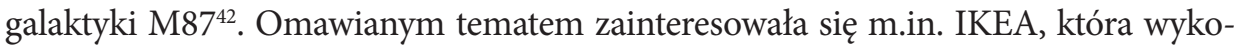
rzystała zjawisko do promocji swoich talerzy DINERA (rysunek 1 oraz rysunek 2).

Należy zwrócić uwagę, że posty pojawily się na profilach marki na Facebooku w wielu różnych państwach, takich jak Austria, Czechy, Węgry, Polska, Serbia oraz Rumunia. Układ grafiki wraz z komunikatem, opis, a także czas publikacji postów w większości krajów jest bardzo podobny. Na ich tle najbardziej wyróżnia się grafika zamieszczona na profilu marki w Austrii, gdzie zastosowano odmienną komunikację oraz kolorystykę (pomarańczową). Co więcej, zamiast tekstu „pierwsze oficjalne zdjęcie” wykorzystano zdanie „czarna dziura Ikea”, a opis postu jest krótszy od pozostałych.

Grafiki opublikowane w pozostałych państwach, m.in. Serbii, Węgrzech, Rumunii, Polsce oraz Czechach, są bardzo do siebie zbliżone i różnią się przede wszystkim wersją językową odpowiednią dla każdej grupy docelowej. Jedynym szczegółem, który wyróżnia grafikę z Polski, jest zielona ramka „Nowość, zamiast pomarańczowej, którą zastosowano w innych krajach. Opis zamieszczony na polskim profilu marki brzmiał następująco „55000 000 lat świetlnych. W takiej odległości od Ziemi znajduje się czarna dziura, której zdjęcie zobaczyliśmy po raz pierwszy. Tymczasem w najbliższym sklepie IKEA zobaczysz inną nowość. Mamy dla Was pierwsze oficjalne zdjęcie!”.

${ }^{42}$ K. Czart, Uzyskano pierwsze zdjęcie czarnej dziury, 2019, https://www.urania.edu.pl/wiadomosci/uzyskano-pierwsze-w-historii-zdjecie-czarnej-dziury (dostęp: 4.02.2020). 
Rysunek 2. Grafiki reklamowe zamieszczone na profilu marki IKEA na Facebooku cz. 2

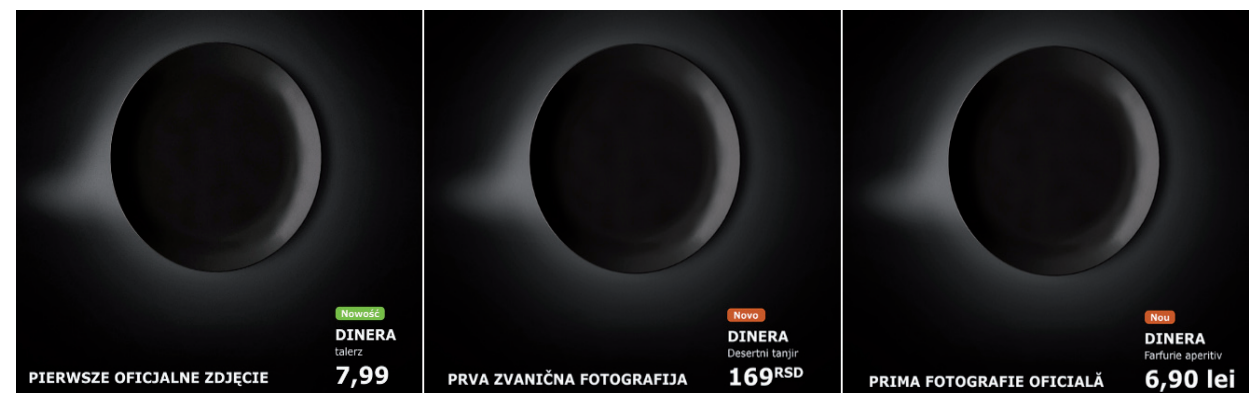

Źródło: https://www.facebook.com/IKEApl, https://www.facebook.com/IKEA.rs, https://www.facebook.com/IKEARomania (dostęp: 3.09.2019).

Podobny motyw (zaćmienie Księżyca) został wykorzystany przez markę Żywiec dwa lata wcześniej, tj. w 2017 roku podczas promocji piwa Żywiec Porter (rysunek 3). Zaćmienie Księżyca to bardzo rzadkie zjawisko, które można zaobserwować bez konieczności wykorzystania specjalistycznej aparatury. Częściowe zaćmienie Księżyca odbywa się średnio dwa razy w roku ${ }^{43}$.

$\mathrm{Na}$ grafice znajduje się butelka piwa, zaćmienie Księżyca oraz komunikat: „W Ż nie bój się ciemności”, zrezygnowano także z opisu dołączonego do postu.

Wykorzystanie litery „Ż” nawiązujące do marki Żywiec stanowi część kampanii promocyjnej, która jest prowadzona od roku 2015. „Ż pojawiało się w komunikatach marki w wielu odsłonach np. „Chce się Ż', „Żona bez Ż to tylko ona” czy „w Ż znajdź swoją drogę"44.

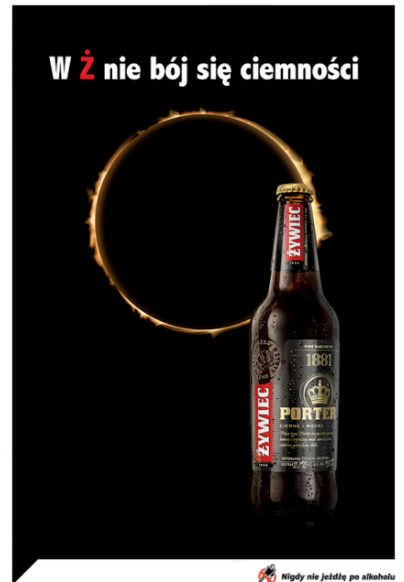

Rysunek 3. Grafiki reklamowe zamieszczone na profilu marki Żywiec na Facebooku

Źródło: https://www.facebook.com/ZywiecMeskimZdaniem (dostęp: 2.09.2019).

43 P. Sadowski, Nie przegap! Zaćmienie księżyca 7 sierpnia 2017, czyli już dziś, 2017, https://www. focus.pl/artykul/nie-przegap-zacmienie-ksiezyca-7-sierpnia-2017-czyli-juz-dzis (dostęp: 4.02.2020).

44 Wiadomościhandlowe.pl, Kolejna współpraca dwóch „Ż”. Cały lipiec trwa wspólna akcja promocyjna Żabki i Żywca, 2019, https://www.wiadomoscihandlowe.pl/artykuly/kolejna-wspolpraca-dwoch-z-caly-lipiec-trwa-wspoln,55662 (dostęp: 19.01.2020). 
Kolejnym bardzo często wykorzystywanym motywem jest motyw filmowy. Marki IKEA oraz Żywiec w swoich komunikatach wielokrotnie nawiązywały m.in. do sagi Gwiezdnych wojen.

Rysunek 4. Grafiki reklamowe zamieszczone na profilu marki IKEA na Facebooku cz. 3
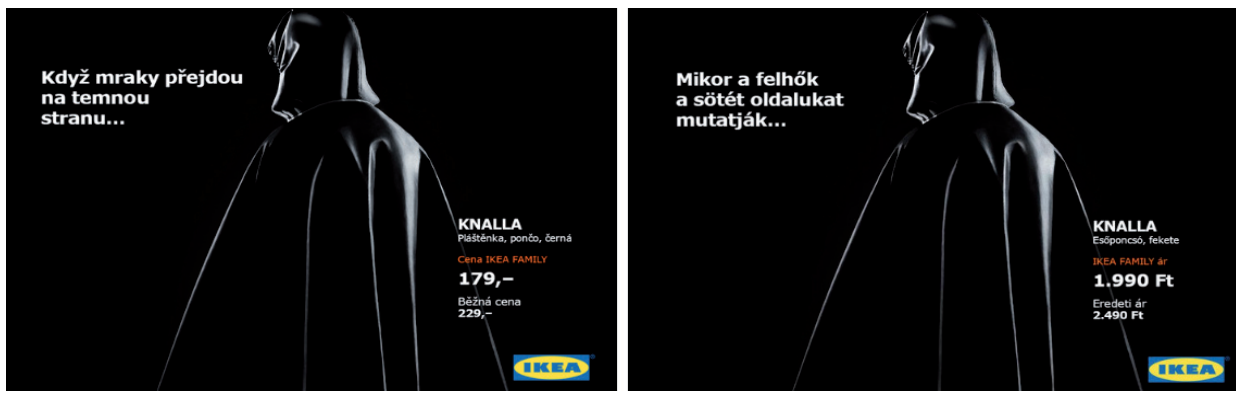

Źródło: https://www.facebook.com/IKEAceska, https://www.facebook.com/IKEAHU (dostęp: 3.09.2019).

Prezentowane posty promują Dzień Star Wars (4 maja) i zostały opublikowane w ten sam dzień w 2018 roku. Data ta jest nieprzypadkowa, ponieważ nawiązuje do popularnego zwrotu „May the force be with you”, czyli „Niech moc będzie z Tobą”. Zdanie to w języku angielskim jest bardzo podobne do komunikatu „May the fourth be with you”, który wskazuje na datę 4 maja. W Polsce Dzień Star Wars odbywa się m.in. w Warszawie, gdzie można spotkać główne postacie sagi, takie jak Lord Vader, szturmowcy, Imperator czy droidy ${ }^{45}$.

Komunikaty opublikowane przez markę IKEA podzielono na dwie grupy. Pierwsza z nich reklamuje pelerynę przeciwdeszczową KNALLA, która odnosi się do kluczowej postaci serii Star Wars, czyli Dartha Vadera (rysunek 4). Posty udostępniono m.in. na profilu marki IKEA Czechy oraz IKEA Węgry. Grafiki są bardzo podobne i dostosowane do lokalnego rynku poprzez zmianę ceny oraz języka komunikatu. Na grafice zamieszczono także wiadomość „Kiedy chmury przejdą na ciemną stronę..., nawiązując tym samym do sagi Gwiezdnych wojen.

Opisy postów są zróżnicowane, jednak każdy z nich nawiązuje do Dnia Gwiezdnych Wojen. Na profilu IKEA Czechy jest to komunikat: „Świętuj Gwiezdne Wojny na swój sposób, bez względu na to, jaką stronę mocy wybierzesz *?", natomiast na Węgrzech: „Bez względu na to, po której jesteś stronie, moc jest zdecydowanie z wami w Dzień Gwiezdnych Wojen!”.

Druga grupa postów promuje lampę stołową FORSA (rysunek 5). Zostały one opublikowane m.in. w Wielkiej Brytanii, Francji i Polsce. Grafiki zawierają bardzo podobny układ graficzny. Różni je komunikat, który w Wielkiej Brytanii oznacza: „Przynieś trochę światła do ciemnej strony pokoju”, natomiast we Francji: „Czy

45 A. Siennica, Dzień „Gwiezdnych Wojen” już 4 maja, 2014, https://naekranie.pl/aktualnosci/ dzien-gwiezdnych-wojen-juz-4-maja (dostęp: 4.02.2020). 
FORSA może być z Tobą?”. Odmienne są także opisy postów (jednak każdy z nich nawiązuje do Dnia Gwiezdnych Wojen).

Rysunek 5. Grafiki reklamowe zamieszczone na profilu marki IKEA na Facebooku cz. 4

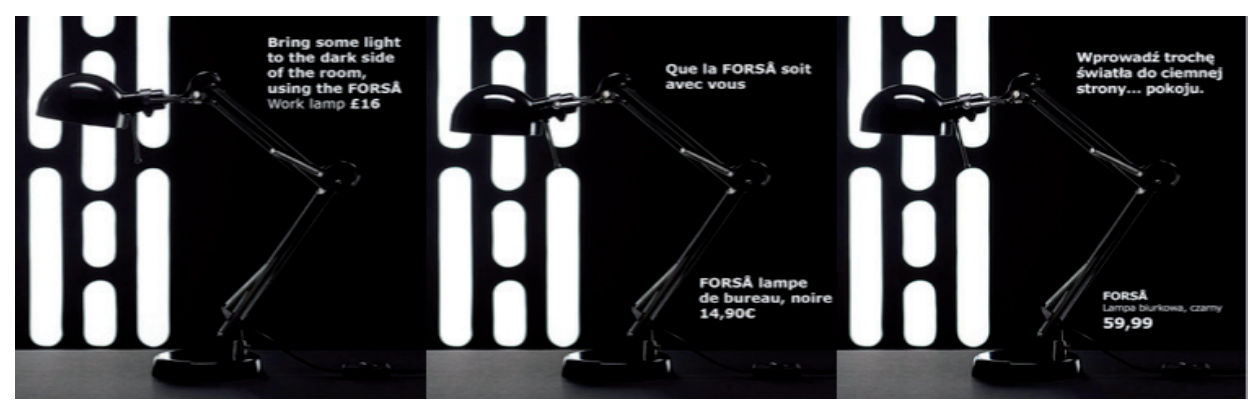

Źródło: https://www.facebook.com/IKEAUK, https://www.facebook.com/IKEAFrance, https://www.facebook.com/IKEApl (dostęp: 1.09.2019).

Dla przykładu w Polsce jest to komunikat: „Lampa dobrze sprawdzi się SOLO..., jak i w większej ilości *F Niech FORSÅ będzie z Wami!”, a we Francji: „Aby chronić Cię przed ciemną stroną. \#StarWarsDay \#MayThe4thBeWithYou” (zawiera on dodatkowo także link do promowanego produktu). Natomiast w Wielkiej Brytanii post jest bardzo krótki i brzmi: „Szczęśliwego czwartego maja”.

Co ciekawe, post na polskim profilu marki IKEA nie został opublikowany 4 maja, a 25 kwietnia, przez co również jego opis uległ zmianie. Za pomocą gry słów nawiązuje jednak do jednego z bohaterów Gwiezdnych wojen, czyli Hana Solo, a dokładniej premiery filmu Han Solo: Gwiezdne wojny - historie.

Motyw Gwiezdnych wojen został także wykorzystany przez markę Żywiec w roku 2014 oraz 2015 (rysunek 6). Opublikowane posty nawiązują do postaci Dartha Vadera, podobnie jak komunikaty stworzone przez markę IKEA. Żywiec na w ciągu dwóch lat promował różne piwa, jednak opis postów jest bardzo podobny i nawiązuje do ciemnej strony mocy. Komunikat z 2014 roku brzmi: „Patrząc z BOCKu, nie wydaje się wcale groźny •-", natomiast z 2015: „Kiedy zapada zmrok, na miasto wychodzi mocny zawodnik ‘".

Rysunek 6. Grafiki reklamowe zamieszczone na profilu marki Żywiec na Facebooku cz. 2
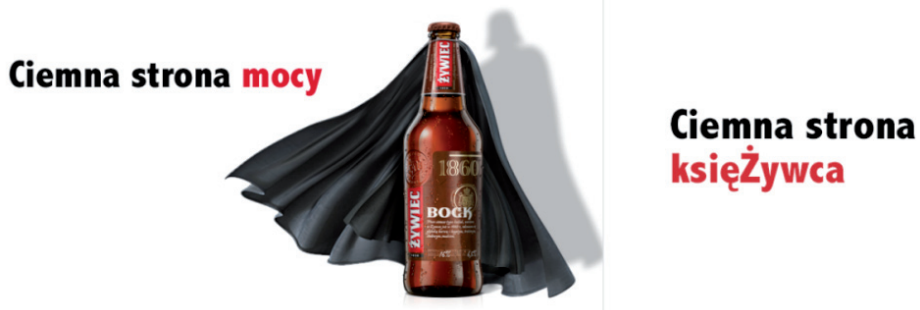

Źródło: https://www.facebook.com/ZywiecMeskimZdaniem (dostęp: 2.09.2019). 
Należy także zauważyć, że Żywiec bardzo interesująco nawiązał do nazwy oraz produktów marki zarówno w opisach, jak i komunikatach umieszczonych na grafikach, tj. „Ciemna strona księŻywca” oraz „Ciemna strona mocy”. Posty z 2014 oraz 2015 roku odnoszą się do nadchodzącej premiery VII części Gwiezdnych wojen: Przebudzenie mocy.

Następnym motywem wykorzystywanym zarówno przez markę IKEA, jak i Żywiec jest serial Gra o tron.

Marka IKEA postanowiła promować zarówno jeden produkt w wielu krajach, jak i inne artykuły należące do jej portfolio.

Stołek MARIUS (rysunek 7) reklamowano m.in. w Rumunii, Serbii i Chorwacji. Grafiki wraz z zamieszczonymi komunikatami w poszczególnych krajach różnią się jedynie ceną, a opisy nawiązują do tanich produktów marki oraz zawierają link do produktów promowanych.

Opis zamieszczony na profilu marki w Rumunii brzmi następująco: „Tron jest przecież zwykłym fotelem $z$ dobrą promocją. Z tego powodu - dlaczego nie wybierzesz takiego, który pomoże Ci zaoszczędzić pieniądze? -) MARIUS czeka na Ciebie w naszym sklepie, wraz z 3000 innych produktów za mniej niż 50 lei”. Posty opublikowano po zakończeniu emisji ostatniego sezonu serialu.

Rysunek 7. Grafiki reklamowe zamieszczone na profilu marki IKEA na Facebooku cz. 5

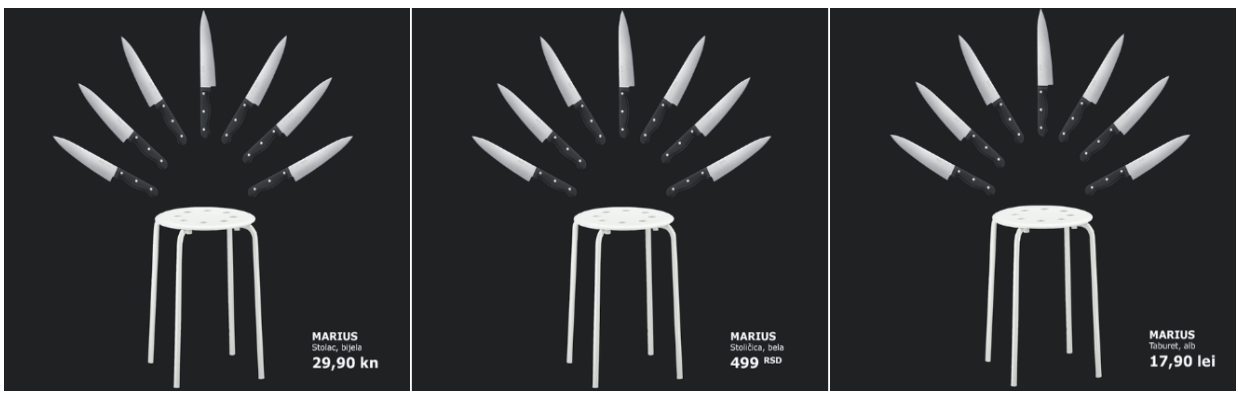

Źródło: https://www.facebook.com/IKEAHrvatska, https://www.facebook.com/IKEA.rs, https://www. facebook.com/IKEARomania (dostęp: 3.09.2019).

Kolejna grupa promuje fotel STRANDMON (rysunek 8) oraz szafkę na buty TRONES (nawiązanie do nazwy serialu). Komunikaty zostały opublikowane podczas rozpoczęcia emisji pierwszego odcinka ostatniego sezonu serialu.

Grafiki przedstawiają fotel oraz prezentują jego różne ujęcia. Udostępniono je na profilu marki zarówno w Estonii, jak i w Czechach. Pierwszy komunikat „Kto dostanie miejsce na tronie? \#gameofthrones” - jest bardzo krótki, zawiera emotikon oraz hasztag i podobnie jak post opublikowany na czeskim profilu marki - „Nadchodzi ostatnia seria Gry o tron! Przygotuj się na obejrzenie tej premiery z własnym wygodnym tronem" - nawiązuje do nowego sezonu serialu. Na grafice umieszczono jednak dodatkowy komunikat: „Kto zasiądzie na tronie?”. 
Grafika w języku polskim promuje szafkę na buty oraz zawiera tekst „Gotowi na nowy sezon?”. Natomiast opis postu odnosi się zarówno do serialu, jak i promowanego produktu oraz posiada odpowiednie hasztagi, tj. „Winter is over. Szykują się wielkie zmiany. Kto zostanie, kto będzie musiał odejść? \#takieButy \#GoT \#nowySezon”. Z pewnością emocje fanów serialu były bardzo duże, szczególnie że komunikaty nawiązywały do ostatniego sezonu serialu, który zyskał bardzo dużą popularność na całym świecie.

Rysunek 8. Grafiki reklamowe zamieszczone na profilu marki IKEA na Facebooku cz. 6
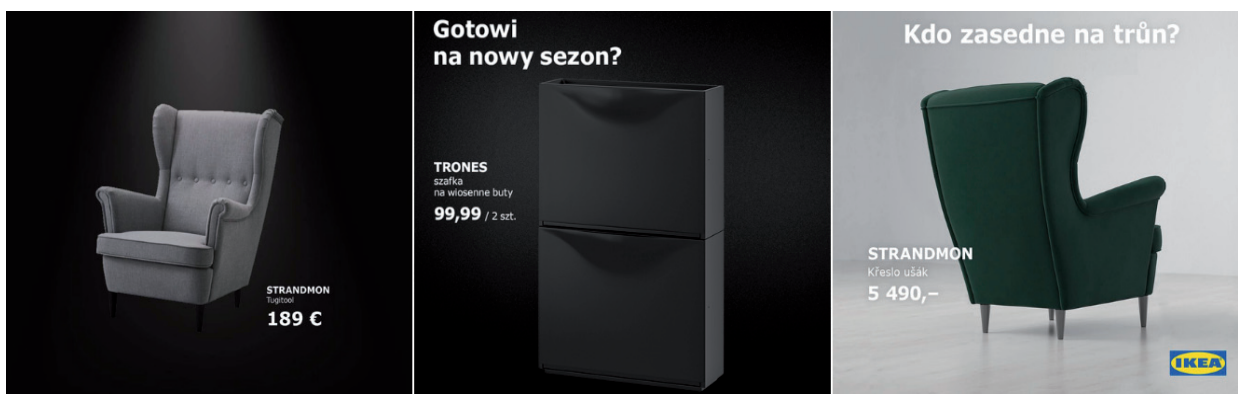

Źródło: https://www.facebook.com/IKEAeesti, https://www.facebook.com/IKEApl, https://www.facebook.com/IKEAceska (dostęp: 3.09.2019).

Także marka Żywiec w kolejnych latach zrealizowała wiele różnorodnych postów nawiązujących do serialu Gra o tron. Pierwszy z nich został opublikowany w 2014 roku, natomiast ostatni w 2019. Grafiki przedstawiają różne rodzaje piw oraz zawierają komunikaty silnie związane z promowanym serialem oraz strategią „Ż”, m.in. „Sezon się skończył, Ż toczy się dalej”, „Walka o Ż”, „Wybran” czy „Gra o tron”. Posty były publikowane podczas rozpoczęcia nowego sezonu serialu (grafiki 1 i 2 nawiązują do rozpoczęcia ostatniego sezonu serialu, podczas gdy grafiki 4 i 5 odnoszą się do rozpoczęcia sezonu 4 oraz 6) albo wystąpienia kluczowego momentu w fabule, a mianowicie zakończenia ostatniego sezonu serialu (grafika 3). Opisy grafik również są bardzo krótkie i związane z fabułą (oprócz grafiki 3). Treść opisu postu na grafice 1 jest następująca: „Czekacie na ósmy sezon?”. Grafika 2 zawiera komunikat: „Zima nadeszła w lipcu”, a trzecia go nie posiada (rysunek 9).

Rysunek 9. Grafiki reklamowe zamieszczone na profilu marki Żywiec na Facebooku cz. 3
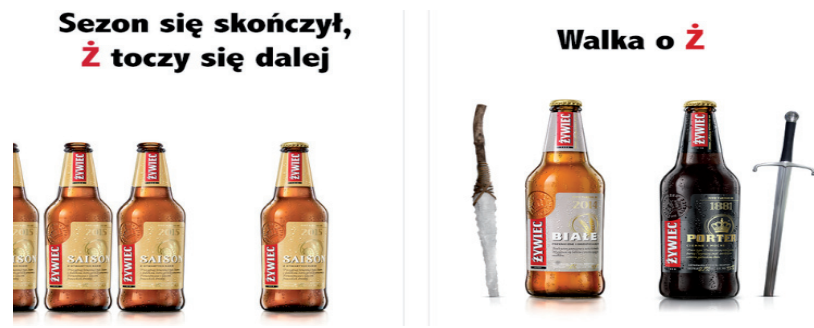

\section{Wybran}

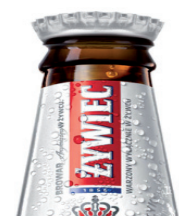

Źródło: https://www.facebook.com/ZywiecMeskimZdaniem (dostęp: 2.09.2019). 
Analizując natomiast rysunek 10, należy wspomnieć, że grafika 4 posiada opis: „Czy Żon Snow powróci? (-)”, podczas gdy grafika 5: „Przy okazji dzisiejszej premiery warto zaopatrzyć się w Żywca na wieczór -2) \#Żywiec”. Trzeba przyznać, że autorzy w kolejnych latach tworzą bardzo kreatywne posty z udziałem produktów marki Żywiec.

Rysunek 10. Grafiki reklamowe zamieszczone na profilu marki Żywiec na Facebooku cz. 4
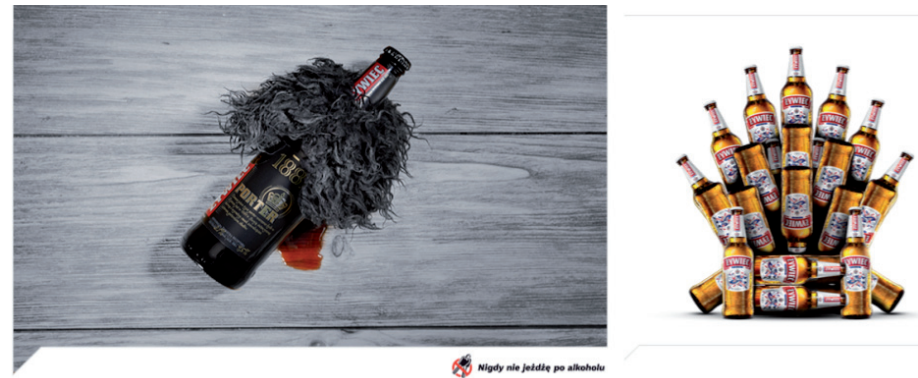

\section{Gra 0 tron}

Źródło: https://www.facebook.com/ZywiecMeskimZdaniem (dostęp: 2.09.2019).

Ostatni przykład poddany analizie nawiązuje do życia publicznego, a dokładniej ślubu księcia Harry’ego i księżnej Meghan, który odbył się 19 maja 2018 roku w kaplicy św. Jerzego na zamku w Windsorze. W ceremonii wzięło udział około 600 osób i można było obejrzeć ją także w telewizji. Uroczystość została określona jako bardzo nowoczesna, ponieważ wyróżniała się wśród innych królewskich wydarzeń ${ }^{46}$. Komunikaty na profilach marki IKEA (m.in. Bułgaria, Francja, Polska) oraz Żywiec nawiązujące do ślubu pary książęcej opublikowano w dniu ceremonii.

Rysunek 11. Grafiki reklamowe zamieszczone na profilu marki IKEA na Facebooku cz. 7

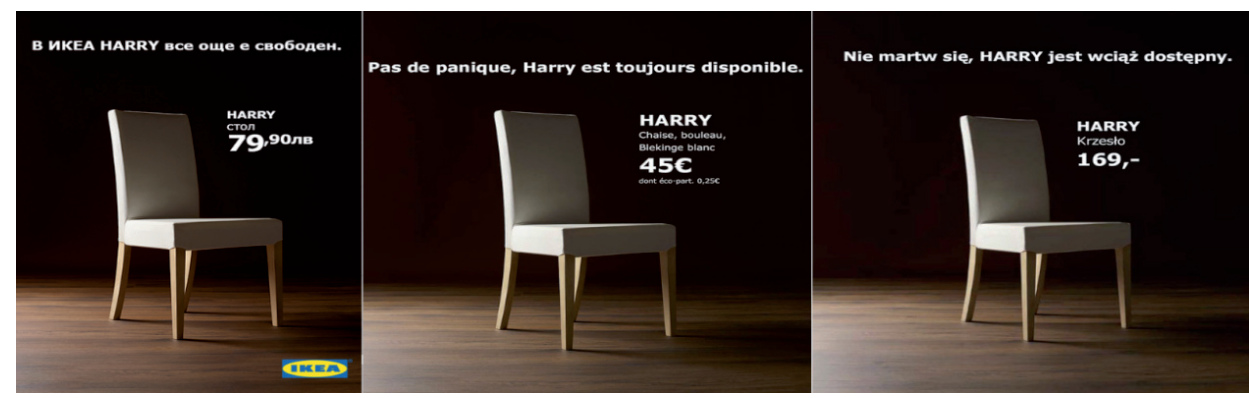

Źródło: https://www.facebook.com/ikeabulgaria/, https://www.facebook.com/IKEAFrance, https:// www.facebook.com/IKEApl (dostęp: 1.09.2019).

${ }^{46}$ Forbes.pl, Książę Harry i Meghan Markle powiedzieli sobie „tak”, 2018, https://www.forbes.pl/ biznes/slub-ksiecia-harryego-i-meghan-markle/6s1b81t (dostęp: 5.02.2020). 
Marka IKEA promuje krzesło HARRY (rysunek 11), a przygotowane przez nią grafiki oraz komunikaty „Nie martw się, Harry jest wciąż dostępny” są identyczne. Podobnie jak opisy postów, które nawiązują do szczęśliwego dnia nie tylko dla pary książęcej, ale także dla klientów marki IKEA, którzy mogą nabyć promowany produkt. Na profilu marki we Francji opis zawiera dodatkowy link do produktu, natomiast w Bułgarii zarówno link, jak i hasztag. W opisie opublikowanym na profilu marki w Polsce umieszczono z kolei odpowiednie emotikony, a jego treść była następująca: „ To szczęśliwy dzień dla pary królewskiej, a może też i dla Ciebie "־”.

Marka Żywiec również zamieściła na swoim profilu posty nawiązujące do pary książęcej (rysunek 12). W tym celu przygotowano specjalną grafikę odnoszącą się do zaistniałej sytuacji, dodano odpowiedni komunikat „Royal Ż”, a także opis związany ze strategią marki „Ż”, o treści: „Dużo szczęścia na nowej drodze Ż!”.

Rysunek 12. Grafiki reklamowe zamieszczone na profilu marki Żywiec na Facebooku cz. 5

\section{Royal $\dot{z}$}

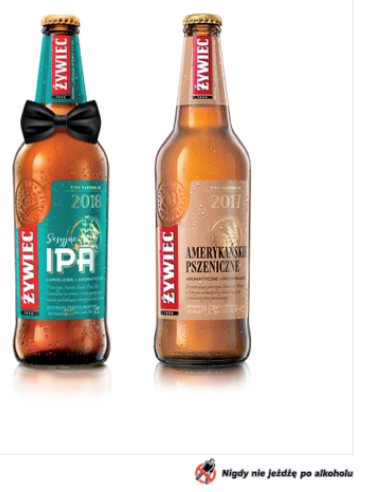

Źródło: https://www.facebook.com/ZywiecMeskimZdaniem (dostęp: 2.09.2019).

Marki IKEA oraz Żywiec zostały także wyróżnione za umiejętność tworzenia komunikatów, które są lekkie oraz nienachalne i sprawiają wrażenie, jakby zostały stworzone bez najmniejszego wysiłku. Jednocześnie promowane produkty są bardzo dobrze wkomponowane w strukturę komunikatu.

Uważa się także, iż opublikowane przez marki posty nawiązujące do Gry o tron czy Gwiezdnych wojen są przykładami jednych z najlepszych działań z zakresu $\mathrm{RTM}^{47}$.

47 B. Goczał, Dzięki akcjom real-time-marketingowym marka staje się kumplem, 2019, https:// www.wirtualnemedia.pl/artykul/dzieki-akcjom-real-time-marketingowym-marka-staje-sie-kumplem (dostęp: 5.02.2020). 


\section{Podsumowanie}

W opublikowanych komunikatach, które wykorzystywały zjawisko RTM, zastosowano marketing treści. Świadczy to o rosnącej popularności tego typu działań, a także zainteresowaniu odbiorców omawianą tematyką. Były to działania zarówno niezaplanowane (zdjęcie czarnej dziury), jak i przewidywalne, które umożliwiały markom odpowiednie przygotowanie komunikatów i ich publikację w najbardziej pożądanym momencie (zaćmienie Księżyca, Dzień Gwiezdnych Wojen, promocja nowego sezonu Gry o tron czy ślub pary książęcej Wielkiej Brytanii).

Wiele motywów działań z zakresu RTM zostało zrealizowanych zarówno przez markę IKEA, jak i Żywiec. Posiadają one również zbliżoną grupę odbiorców, tematykę publikowanych postów oraz kanały komunikacji (tradycyjne, a także digital). Wyznaczona przez nich misja jest spójna i odnosi się do tworzenia wyjątkowych wartości dla interesariuszy. To m.in. dbanie o ludzi i środowisko oraz zapewnienie zrównoważonego rozwoju.

Posty stworzone przez markę Żywiec oraz IKEA zawierają interesujące grafiki promujące produkty z ich portfolio. Grafiki przygotowane przez markę Żywiec są bardzo spójne, zazwyczaj posiadają białe tło, butelkę piwa zawierającą określony atrybut związany z treścią komunikatu, a także krótką wiadomość. Dzięki powtarzającemu się układowi graficznemu odbiorcy są świadomi struktury przekazu i silniej się z nim utożsamiają.

Posty udostępniane przez markę IKEA prezentują natomiast określone produkty, ale nie posiadają dodatkowych atrybutów nawiązujących do wybranego motywu. Często jest to jedynie odniesienie do nazwy produktu spójnego z tematyką przekazu. Działania te pokazują, że marka IKEA potrafi zastosować grę słów w bardzo interesujący sposób, wymagając od odbiorcy identyfikacji kontekstu opublikowanego komunikatu. W komunikacji wykorzystano także m.in. różnorodne hasztagi oraz emotikony. Ze względu na fakt, iż na grafikach udostępnionych przez markę IKEA znajdują się ceny oraz linki umożliwiające zakup produktów, można odnieść wrażenie, że posiadają one bardziej komercyjny charakter niż grafiki promujące markę Żywiec.

Opublikowane posty udowodniły, że marki posiadają poczucie humoru, są na bieżąco z istotnymi tematami społecznymi i potrafią szybko zareagować na zmiany. Działania z zakresu RTM przynoszą głównie korzyści wizerunkowe, które wpływają m.in. na zwiększenie zasięgu opublikowanych komunikatów. Należy jednak pamiętać, że promowany produkt powinien stanowić uzupełnienie przekazu, a nie jego główną część. Istotna jest także świadomość, że nie wszystkie marki mogą opublikować komunikaty tego typu. Ich udostępnienie jest warunkowane m.in. poprzez grupę docelową marki, a także cel i misję organizacji.

Celem wykorzystania działań z zakresu RTM przez marki IKEA oraz Żywiec było zarówno zwiększenie zainteresowania odbiorców wybraną tematyką, jak i zaproszenie ich do wzajemnego dialogu poprzez komentowanie, udostępnianie oraz 
reagowanie na opublikowane posty. Dzięki działaniom z zakresu RTM marki nawiązują unikatowe relacje z odbiorcami, zwiększają ich zaufanie oraz zmniejszają poziom utraty klienta. Co więcej, ich publikacja wiąże się z niewielkimi kosztami przekładającymi się na wysoką efektywność podejmowanych działań.

\section{Bibliografia}

Andrzejewska P., Wykorzystanie marketingu internetowego w podnoszeniu konkurencyjności przedsiębiorstw branży browarniczej w Polsce (rozprawa doktorska), 2016, https://r.uek. krakow.pl/bitstream/123456789/ 2803/1/1200003254.pdf (dostęp: 13.01.2020).

BlueVenn, Real-Time Marketing Tactical Guide, https:/www.bluevenn.com/hubfs/files/RealTime\%20Marketing\%20Tactical\%20Guide\%20eBook.pdf?ref=zest.is (dostęp: 5.09.2019).

Czart K., Uzyskano pierwsze zdjęcie czarnej dziury, 2019, https://www.urania.edu.pl/wiadomosci/uzyskano-pierwsze-w-historii-zdjecie-czarnej-dziury (dostęp: 4.02.2020).

Dudowskiy J., IKEA Segmentation, Targeting and Positioning: Targeting Cost-Conscious Customers, 2019, https://research-methodology.net/ikea-segmentation-targeting-positioning-targeting-cost-conscious-customers/ (dostęp: 13.01.2020).

Essays, UK, Ikea Communication Strategy in the Global Environment, 2018, https://www. ukessays.com/essays/marketing/a-case-study-of-ikea-with-global-communication-marketing-essay.php (dostęp: 14.01.2020).

Forbes.pl, Książę Harry i Meghan Markle powiedzieli sobie „tak”, 2018, https://www.forbes.pl/ biznes/slub-ksiecia-harryego-i-meghan-markle/6s1b81t (dostęp: 5.02.2020).

Goczał B., Dzięki akcjom real-time-marketingowym marka staje się kumplem, 2019, https:// www.wirtualnemedia.pl/artykul/dzieki-akcjom-real-time-marketingowym-marka-staje-sie-kumplem (dostęp: 5.02.2020).

Gregor B., Kłosińska J., Zastosowanie koncepcji real-time marketingu w komunikacji z klientem, „Zeszyty Naukowe Uniwersytetu Szczecińskiego. Ekonomiczne Problemy Usług” 2015, nr 117, s. 111-122.

Grupa Żywiec, Warzymy lepszy świat. Raport wpływu grupy kapitałowej Żywiec za 2016 rok, https:/grupazywiec.pl/wp-content/uploads/2017/08/Warzymy-Lepszy-\%C5\%9Awiat-Raport-wp\%C5\%82ywu-Grupy-Kapita\%C5\%82owej-\%C5\%BBywiec-za-2016-rok-16-sierpnia.compressed.pdf (dostęp: 14.01.2020).

Gugniewicz J., Marki na przełomie 2019/2020: IKEA, 2019, https://nowymarketing.pl/a/24344, marki-na-przelomie-2019-2020-ikea (dostęp: 14.01.2020).

Gugniewicz J., Marki na przełomie 2019/2020: Żywiec, 2019, https://nowymarketing.pl/a/ 24301,marki-na-przelomie-2019-2020-zywiec (dostęp: 14.01.2020).

https://www.facebook.com (dostęp: 1-3.09.2019).

https://grupazywiec.pl (dostęp: 26.10.2019).

https://www.ikea.com (dostęp: 26.10.2019).

https://www.industry.ikea.pl (dostęp: 14.01.2019).

Kieżel M., Reakcje przedsiębiorstwa na wydarzenia kulturalne jako przejaw stosowania real-time marketingu, „Studia Ekonomiczne. Zeszyty Naukowe Uniwersytetu Ekonomicznego w Katowicach" 2018, nr 371, s. 17-31.

Ledzian P., Real-Time Marketing, [w:] M. Czajkowska, M. Malarski (red.), Funkcjonowanie e-biznesu. Zasoby, procesy, technologie, Wydawnictwo Uniwersytetu Łódzkiego, Łódź 2015, s. 89-97. 
Lieb R., Real-Time Marketing: The Ability to Leverage Now, 2013, https://rebeccalieb.com/sites/default/files/downloads/1312\%20Real-Time\%20Marketing\%20 RL.pdf (dostęp: 18.09.2019).

Money.pl, Marka Żywiec odmładza wizerunek, 2013, https://manager.money.pl/news/artykul/ marka;zywiec;odmladza;wizerunek,164,0,1272484.html (dostęp: 13.01.2020).

ProperAD.pl, Real-Time Marketing i jego sekrety, 2019, https://properad.pl/artykul/63/Real-Time-Marketing-i-jego-sekrety (dostęp: 22.09.2019).

Sadowski P., Nie przegap! Zaćmienie księżyca 7 sierpnia 2017, czyli już dziś, 2017, https://www. focus.pl/artykul/nie-przegap-zacmienie-ksiezyca-7-sierpnia-2017-czyli-juz-dzis (dostęp: 4.02.2020).

Sanchez Torres W.C., Restrepo J.C., Strategic Real-Time Marketing, [w:] D. Juárez Varón, M. Expósito Langa, J.V. Tomás Miquel, M. Cruz Fernández Madrid (red.), Marketing Research Notebooks, Editorial ISEUN, Alicante 2015, s. 164-184.

Siennica A., Dzień „Gwiezdnych Wojen” już 4 maja, 2014, https://naekranie.pl/aktualnosci/ dzien-gwiezdnych-wojen-juz-4-maja (dostęp: 4.02.2020).

Summak M., E., Ar1 I., The Influence of Real-Time Marketıng on Social Media Users: A Study on Users of 'Ekşi Sözlük', „Sosyal Bilimler Meslek Yüksekokulu Dergisi” 2015, vol. 18, nr 1.

Szarf D., Real-Time Marketing - na czym polega i od czego zaczaćc?, https://blog.brand24.pl/ real-time-marketing-na-czym-polega-i-od-czego-zaczac/ (dostęp: 20.09.2019).

Szymańska K., Wykorzystanie real-time marketingu jako narzędzia budowania wizerunku firmy w social media, „Zarządzanie Mediami” 2015, t. 3, nr 4, s. 269-279, http://www.ejournals.eu/ ZM/Tom-3/4-2015/art/7193/ (dostęp: 5.09.2019).

Wiadomościhandlowe.pl, Kolejna współpraca dwóch „Ż”. Cały lipiec trwa wspólna akcja promocyjna Żabki i Żywca, 2019, https://www.wiadomoscihandlowe .pl/artykuly/kolejna-wspolpraca-dwoch-Z-caly-lipiec-trwa-wspoln,55662 (dostęp: 19.01.2020).

Willemsen L.M., Mazerant K., Kamphuis A.L., van der Veen G., Let's Get Real (Time)! The Potential of Real-Time Marketing to Catalyze the Sharing of Brand Messages, „International Journal of Advertising" 2018, vol. 37, nr 5, s. 828-848. 